\title{
POLA MIGRASI DAN FAKTOR-FAKTOR YANG BERHUBUNGAN DENGAN MIGRASI PENDUDUK DI KECAMATAN PADANG TIJI
}

\author{
Mujiburrahmad $^{1 *}$, Ahmad Humam Hamid ${ }^{1}$, Tazliatun Nufus ${ }^{1}$ \\ ${ }^{1}$ Universitas Syiah Kuala, Indonesia \\ *e-mail: mujiburrahmad@unsyiah.ac.id
}

\begin{abstract}
Abstrak
Migrasi merupakan salah satu faktor yang mempengaruhi pertumbuhan penduduk dan menjadi faktor ketidakmerataan pertumbuhan ekonomi wilayah. Penelitian ini bertujuan untuk mengetahui faktorfaktor yang berhubungan dengan terjadinya migrasi penduduk dan pola migrasi para migran di Kecamatan Padang Tiji Kabupaten Pidie. Penelitian mengambil sampel di tiga desa di Kecamatan Padang Tiji. Pemilihan lokasi ini menggunakan metode purposive sampling. Proses pengambilan data diperoleh dari wawancara terhadap 50 responden. Metode analisis yang digunakan dalam penelitian ini yaitu metode deskriptif kualitatif. Hasil penelitian menunjukkan bahwa faktor-faktor yang berhubungan dengan migrasi permanen dan nonpermanen yang paling banyak pada responden yaitu faktor penarik, faktor individu dan faktor pendorong. Kemudian Pola migrasi para migran di Kecamatan Padang Tiji Kabupaten Pidie yang paling banyak adalah migrasi secara non permanen sebanyak $60 \%$ dari 50 jumlah responden. Sedangkan migrasi permanen sebanyak $40 \%$ dari 50 jumlah responden. Daerah tujuan migrasi bukan hanya di Kabupaten-Kabupaten di Provinsi Aceh saja. Akan tetapi juga tersebar ke luar kota (Medan, Jakarta, Jawa, dan Lampung) dan juga keluar negeri seperti Negara Malaysia. Adapun alasan responden memilih migrasi ke luar kota ialah pekerjaan lebih mudah didapat, adanya kerabat didaerah tujuan, dan pendapatan yang diperoleh lebih tinggi. Keputusan migran ke negara Malaysia untuk mencari pekerjaan baru yang dianggap lebih menguntungkan dari daerah. Adapun alasan paling dominan yang menarik keinginan migran untuk melakukan migrasi ke Negara Malaysia adalah karena upah kerja yang tinggi. Upah kerja yang ditawarkan dalam bentuk mata uang asing sangatlah menggiurkan, jika dibandingkan mata uang asing, maka nilai tukar rupiah masih sangat rendah.
\end{abstract}

Kata kunci: Pola Migrasi; Faktor-Faktor Migrasi; Penduduk

\begin{abstract}
Migration is one of the factors that affect population growth and becomes the factor of inequality in economic growth in an area. This study aims to determine what factors are associated with population migration and migration patterns of migrants in Padang Tiji District, Pidie Regency. The study took samples in three villages in the District of Padang Tiji. The selection of this location used the purposive sampling method. The data collection process was obtained from interviews with 50 respondents. The analytical method used in this research is the descriptive qualitative method. The results showed that the factors associated with permanent and non-permanent migration were the most common in respondents, namely pull factors, individual factors, and push factors. Then the migration pattern of migrants in Padang Tiji District, Pidie Regency, the most is non-permanent migration as much as $60 \%$ of the 50 respondents. Meanwhile, permanent migration is $40 \%$ of the 50 respondents. Migration destinations are not only in the districts in Aceh Province. However, it is also spread outside the city (Medan, Jakarta, Java, and Lampung) and also abroad, such as Malaysia. The reasons respondents choose to migrate out of town are that jobs are easier to get, relatives in the destination area, and higher income. The decision of migrants to Malaysia to find new jobs that are considered more profitable from the region. The most dominant reason that attracts the desire
\end{abstract}

Doi: http://dx.doi.org/10.23887/jish-undiksha.v10i3.34757 Jurnal IImu Sosial dan Humaniora| 419 
of migrants to migrate to Malaysia is because of high work wages. The wages offered in foreign currencies are very tempting. When compared to foreign currencies, the rupiah exchange rate is still shallow.

Keywords: Migration Pattern; Migration Factors; Population

This is an open access article under the CC BY-SA license.

\section{PENDAHULUAN}

Laju pertumbuhan penduduk di suatu daerah dipengaruhi oleh migrasi. Migrasi menggambarkan kondisi dimana perkembangan ekonomi yang tidak merata pada suatu wilayah, penyebabnya adalah terbatasnya akses terhadap sumberdaya alam serta adanya kesenjangan kondisi ekonomi masyarakat di suatu wilayah. Umumnya migrasi terjadi akibat seseorang ingin mencari penghidupan yang lebih layak. Kehidupan yang layak dapat di ukur dari beberapa indikator yaitu ekonomi, kondisi social, fasilitas kesehatan, fasilitas pendidikan, serta politik dan budaya yang lebih baik dengan daerah asal.

Permasalahan migrasi yang sering terjadi adalah adanya faktor pendorong dan penarik bagi individu dalam melakukan migrasi, salah satu faktornya adalah faktor sebaran dan distribusi penduduk yang tidak merata. (Susilowati, 2005).

Migrasi juga dipengaruhi oleh faktor tidak meratanya fasilitas pembangunan antara satu wilayah dengan wilayah lainnya. Akibat dari ketidakmerataan ketersediaan fasilitas pembangunan, akan tercipta pekerja dari wilayah yang tidak memiliki fasilitas pembangunan Akan pergi ke wilayah yang memiliki fasilitas pembanguna, yaitu antara wilayah pedesaan dengan wilayah perkotaan. Faktor lain adanya migrasi dari desa ke kota disebabkan oleh tidak meratanya pembangunan di pedesaan jika dibandingkan dengan kemajuan perkotaan dan juga disebabkan oleh karakteristik sosialekonomi dan sosial-budaya wilayah yang bersangkutan (Saefullah, 1994).

Kondisi sosial-ekonomi dan sosial-budaya di wilayah asal yang tidak memungkinkan untuk memenuhi kebutuhannya menyebabkan orang tersebut ingin migrasi ke wilayah lain yang dapat memenuhi kebutuhannya. Setiap orang mempunyai kebutuhan yang berbeda-beda, maka penilaian terhadap wilayah asal dari masingmasing individu di masyarakat tersebut juga akan berbeda-beda, sehingga proses pengambilan keputusan untuk migrasi dari masingmasing individu berbeda pula (Mantra, 2015).

Persoalan migrasi banyak dialami oleh negara yang sedang berkembang, termasuk beberapa daerah di Indonesia. Fenomena yang terjadi adanya tenaga kerja yang berasal dari pedesaan yang bekerja di perkotaan. Fenomena migrasi yang terjadi masih dianggap wajar karena

Jurnal IImu Sosial dan Humaniora | 420 
pedesaan akan menyalurkan tenaga kerja ke perkotaan yang mempunyai lapangan kerja lebih banyak, namun pada faktanya jumlah tenaga kerja yang berpindah dari desa ke perkotaan telah melebihi tingkat ketersediaan lapangan kerja di perkotaan, sehingga melebihi daya tampung sektor industri dan jasa di perkotaan. (Todaro \& Smith, 2003).

Persoalan migrasi masyarakat desa ke kota cenderung dipengaruhi oleh faktor ekonomi. Faktor ekonomi mendorong munculnya pergerakan migrasi, bukan saja sebagai faktor pendorong yang berasal dari sektor pertanian atau dari desanya sendiri. Akan tetapi ada juga faktor penarik dari sektor industri di daerah perkotaan, seperti misalnya gaji yang lebih tinggi (Todaro, 1993). (Mantra, 2015) menyatakan bahwa keinginan utama seseorang bermigrasi dari desa ke kota karena adanya motif ekonomi. Motif ekonomi berkembang karena munculnya perbedaan antar daerah. Munculnya keinginan untuk mendapatkan pendapatan dan pekerjaan yang lebih baik dibadingkan yang didapatkan di daerah asal membuat seseorang melakukan migrasi.

Migrasi akan mempengaruhi tiap masyarakat secara selektif akan ekonomi, pendidikan, sosial dan demografi. Masing-masing individu akan berbeda dalam menerima pengaruh terhadap faktor ekonomi dan non ekonominya. Perbedaan yang muncul tidak saja terdapat pada arus migrasi antara negara dan antar wilayah nasional, melainkan juga antar wilayah dalam negara yang sama. Munculnya pengaruh faktor sosial-ekonomi terhadap migrasi dari desa ke kota meliputi jenis kelamin, biaya migrasi, usia, status pernikahan, pendidikan dan pekerjaan (Todaro \& Smith, 2003).

Kabupaten Pidie dengan luas wilayah 3,562.14 km2 dengan jumlah penduduk pada tahun 2019 sebanyak 432,599 jiwa yang terdiri atas 209.272 jiwa penduduk laki-laki dan 223.327 jiwa penduduk perempuan. Penduduk Kabupaten Pidie mengalami pertumbuhan sebesar 1,56 persen dari tahun 2018. Kepadatan penduduk di Kabupaten Pidie tahun 2019 mencapai 121 jiwa/km2 dengan ratarata jumlah penduduk per rumah tangga 4 orang.

Kepadatan Penduduk di 23 kecamatan jika dilihat berdasarkan data sangat bervariasi dengan kepadatan penduduk tertinggi terdapat di Kecamatan Kota Sigli dengan kepadatannya 2.204 jiwa/km2 dan kepadatan terendah ada di Kecamatan Mane 11 jiwa/Km2. Untuk Tingkat partisipasi angkatan kerja penduduk di Kabupaten Pidie sebesar $63,05 \%$ dengan $74,41 \%$ penduduk laki-laki dan 52,87\% penduduk perempuan. Sedangkan untuk data tingkat pengangguran penduduk di Kabupaten Pidie sebesar 7,64 persen (Badan Pusat Statistik, 2019). Kepadatan penduduk mendorong sebagian warga di Kabupaten Pidie bermigrasi keluar daerah menjadi pilihan untuk mencari pekerjaan atau perubahan di luar Kabupaten Pidie sesuai dengan data migrasi di Tabel 1. 
Tabel 1. Migrasi Masuk Seumur Hidup dan Migrasi Keluar Seumur Hidup di Kabupaten Pidie Tahun 2019

\begin{tabular}{clr}
\hline Jenis Migrasi & Jenis Kelamin & Jumlah Penduduk (Jiwa) \\
\hline \multirow{2}{*}{ Migrasi Masuk } & Laki-laki & 6.113 \\
& Perempuan & 4.944 \\
& Jumlah & 11.057 \\
& Laki-laki & 196.386 \\
Migrasi Keluar & Perempuan & 210.730 \\
& Jumlah & 407.116 \\
\hline
\end{tabular}

Sumber: BPS Provinsi Aceh, 2019

Migrasi seumur hidup disebut bila provinsi tempat tinggal seseorang pada saat pencacahan berbeda dengan provinsi tempat lahirnya. Migrasi masuk seumur hidup adalah masuknya penduduk ke suatu daerah tujuan. Dapat dilihat pada tabel diatas jumlah migrasi masuk ke Kabupaten Pidie adalah 11.057 jiwa dengan jumlah laki-laki 6.113 jiwa dan perempuan 4.944 jiwa. Migrasi keluar seumur hidup adalah perpindahan penduduk keluar dari suatu daerah asal. Dapat dilihat pada tabel di atas angka migrasi keluar seumur hidup sangat tinggi yaitu 407.116 jiwa dengan jumlah laki-laki 196.386 jiwa dan perempuan sebanyak 210.730 jiwa (Badan Pusat Statistik, 2019). Oleh karena itu, penelitian ini ialah migrasi keluar dari Kecamatan Padang Tiji Kabupaten Pidie ke wilayah-wilayah lainnya. Banyaknya migrasi keluar disebabkan oleh tidak terpenuhinya keinginan penduduk didaerah asal sehingga mencari penghidupan yang lebih layak di daerah lain (Mantra, 2015).

Kabupaten Pidie merupakan salah satu wilayah yang memiliki banyak area lahan pertaniannya dan rata-rata pekerjaan utama penduduknya adalah dibidang pertanian. Kecamatan Padang Tiji merupakan salah satu kecamatan di Kabupaten Pidie yang mempunyai lahan sawah yang paling luas diantara kecamatan-kecamatan lainnya di Kabupaten Pidie yaitu sebesar 5.300 Ha (Badan Pusat Statistik, 2019). Tujuan dari penelitian ini adalah untuk mengetahui faktor-faktor yang berhubungan dengan migrasi penduduk, dan mengetahui pola migrasi para migran di Kecamatan Padang Tiji Kabupaten Pidie.

\section{METODE}

Penelitian ini dilakukan di 3 (tiga) desa di Kecamatan Padang Tiji Kabupaten Pidie yaitu Desa Buloh Peudaya, Buloh Gogo, dan Hagu Kunyet. Pemilihan lokasi ini menggunakan metode purposive sampling. Populasi dalam penelitian ini adalah penduduk yang melakukan migrasi keluar dari Kecamatan Padang Tiji Kabupaten Pidie. Sampel yang diambil ialah penduduk yang pernah melakukan migrasi atau penduduk yang sedang bermigrasi. Penduduk yang pernah migrasi akan diwawancari secara langsung oleh peneliti sedangkan untuk responden yang sedang migrasi dan tidak ada di tempat maka akan diwawancarai pada

Jurnal IImu Sosial dan Humaniora | 422 
keluarganya atau kerabatnya. Oleh karena itu, dalam wawancara ini memiliki kekurangan pada responden yang sedang migrasi atau tidak berada ditempat karena tidak diwawancarai secara langsung pada respondennya.

Namun tidak dapat dipungkiri bahwa pada saat seseorang keluarga atau kerabat yang melakukan migrasi, pastinya keluarga tersebut akan mengetahui alasan anggota keluarganya tersebut bermigrasi sehingga jawaban yang disampaikan oleh keluarganya dapat dipercaya. Jumlah responden dalam penelitian ini 50 orang. Metode survei digunakan dalam pengumpulan data dengan cara mengumpulkan data dan menganalisa fakta sesuai dengan kondisi yang ditemukan di lapangan. Data disajikan secara tabelaris kemudian diuraikan secara deskriptif kualitatif.

\section{HASIL DAN PEMBAHASAN Faktor-Faktor Yang Berhubungan Dengan Migrasi Penduduk}

\section{Migrasi Permanen}

Faktor-faktor yang berhubungan dengan migrasi penduduk permanen yang paling banyak ialah faktor penarik (pekerjaan di daerah tujuan sebesar $25 \%$, pendapatan di daerah tujuan sebesar 15\%, fasilitas pendidikan sebesar $15 \%$ dan fasilitas kota sebesar 5\%).

Adanya pekerjaan di daerah tujuan menyebabkan responden melakukan migrasi. Seperti pendapat Maulida (2013) yang menyebutkan bahwa adanya kesempatan memperoleh pekerjaan yang lebih baik di daerah tujuan menjadi faktor penarik migrasi. Kemudian di dukung oleh penelitian Syamsuddin (2020) yang menyatakan bahwa luasnya lapangan kerja dan adanya pekerjaan yang beragam di daerah kota menjadi alasan melakukan migrasi.

Salah satu alasan melakukan migrasi ialah pendapatan didaerah tujuan lebih tinggi. Susahnya mendapatkan penghasilan di wilayah asal dan adanya kemungkinan mendapatkan penghasilan yang lebih baik di wilayah tujuan migrasi menjadi sebab yang paling dominan yang mendorong orang tersebut melakukan migrasi. Sulitnya memperoleh pendapatan di daerah asal dan kemungkinan untuk memperoleh pendapatan yang lebih baik di daerah. Seperti hasil penelitian Tajuddin et al., (2015) mereka yang bekerja di kota punya cita-cita untuk dapat meningkatkan taraf ekonomi keluarganya menjadi lebih baik. Hal ini sesuai dengan penelitian Pratama (2012) yang menyebutkan pilihan seseorang untuk bermigrasi tergantung pada selisih dari jumlah pendapatan yang di dapatkan di desa dengan jumlah yang diinginkan di kota. Faktor penghasilan adalah alasan utama yang dapat mempengaruhi masyarakat desa untuk melakukan migrasi. Sama halnya dengan teori yang dikemukan oleh Rahmi \& Rudiarto, (2013) yang menyatakan bahwa ada faktor pendorong dan faktor penarik migrasi, misalnya ada peluang dan kesempatan untuk memperbaiki kehidupan, tersedianya peluang untuk dapat memperoleh pendidikan yang

Jurnal IImu Sosial dan Humaniora | 423 
lebih baik, serta adanya aktivitasaktivitas di kota besar, tersedianya tempat hiburan dan pusat kebudayaan.

Kemudian faktor individu (variabel status pernikahan mempunyai hubungan paling besar yaitu $30 \%$, tingkat pendidikan $5 \%$, sedangkan variabel umur dan jenis kelamin tidak mempunyai hubungan). Hasil penelitian ini sesuai dengan penelitian terdahulu Sukamdi et al., (2015), dan penelitian Gunawan, (2016) orang yang berstatus menikah lebih banyak melakukan migrasi secara permanen dikarenakan orang yang sudah menikah akan mengikuti suami ataupun sebaliknya. Semakin tinggi tingkat Pendidikan migran maka akan semakin besar peluang untuk melakukan migrasi.

Puspitasari \& Mudakir, (2010) mengemukakan bahwa masyarakat yang memiliki tingkat pendidikan lebih tinggi akan melakukan migrasi lebih banyak dibandingkan yang berpendidikan rendah. Secara umum dapat dijelaskan bahwa meningkatnya pendidikan masyarakat akan meningkatkan migrasi. Pendidikan yang tinggi akan mempengaruhi pola pikir individu untuk memperoleh pendapatan yang lebih baik. Meningkatnya pendidikan masyarakat akan meningkatkan pendapatan migran, sehingga dapat menurunkan biaya migrasi.

Faktor pendorong juga mempunyai hubungan dengan migrasi penduduk yaitu pada variabel pekerjaan di daerah asal yaitu sebesar $5 \%$, sedangkan variabel pendapatan di daerah asal, kepemilikan lahan, dan bencana alam tidak mempunyai hubungan dengan migrasi penduduk secara permanen di Kecamatan Padang Tiji Kabupaten Pidie.

Tidak adanya lapangan kerja di wilayahnya menyebabkan responden melakukan migrasi. Hal ini sejalan dengan teori Sudibia et al., (2012) yang mengatakan ada faktor pendorong migrasi yaitu tidak adanya pekerjaan di daerah asal menyebabkan masyarakat merasa memiliki peluang untuk mendapatkan pekerjaan di tempat tujuan migrasinya. Data lengkap faktor-faktor yang berhubungan dengan migrasi permanen disajikan pada Tabel 2.

Tabel 2. Faktor-Faktor yang Berhubungan dengan Migrasi Permanen

\begin{tabular}{cclcc}
\hline No & \multicolumn{1}{c}{ Faktor } & \multicolumn{1}{c}{ Variabel } & Frekuensi $(\mathrm{n})$ & Presentase (\%) \\
\hline \multirow{4}{*}{1} & \multirow{3}{*}{ Faktor Pendorong } & Pekerjaan didaerah asal & 1 & 5 \\
& & Pendapatan didaerah asal & 0 & 0 \\
& & Kepemilikan Lahan & 0 & 0 \\
& Bencana alam & 0 & 0 \\
\hline \multirow{3}{*}{2} & \multirow{3}{*}{ Faktor Penarik } & Pekerjaan didaerah tujuan & 5 & 25 \\
& & Pendapatan didaerah tujuan & 3 & 15 \\
& & Fasilitas pendidikan & 3 & 15 \\
& & Fasilitas kota & 1 & 5 \\
\hline \multirow{3}{*}{3} & \multirow{3}{*}{ Faktor Individu } & Umur & 0 & 0 \\
& & Tingkat pendidikan & 1 & 5 \\
& & Status pernikahan & 6 & 30 \\
& & Jenis kelamin & 0 & 0 \\
\hline
\end{tabular}


Total

\section{Migrasi Nonpermanen}

Faktor-faktor yang berhubungan dengan migrasi penduduk nonpermanen yang paling banyak yaitu faktor penarik (pekerjaan di daerah tujuan sebesar $17 \%$, pendapatan di daerah tujuan sebesar $27 \%$, fasilitas pendidikan sebesar 20 $\%$ dan fasilitas kota sebesar $3 \%$ ). Kemudian faktor pendorong (pekerjaan di daerah asal sebesar 10 $\%$, pendapatan di daerah asal sebesar $7 \%$, kepemilikan lahan sebesar $3 \%$ dan bencana alam tidak mempunyai hubungan dengan migrasi penduduk di Kecamatan Padang Tiji Kabupaten Pidie ini).

Pendapatan di tempat asal yang rendah akan mendorong penduduk untuk melakukan migrasi. Hal ini sejalan dengan hasil penelitian Trendyari \& Yasa, (2014) yang menyatakan bahwa pendapatan mempunyai pengaruh positif dengan keputusan melakukan migrasi, semakin besar pendapatan yang diperoleh di daerah tujuan maka akan semakin besar peluang migran untuk melakukan migrasi.

Luas Iahan menjadi salah satu alasan para migran melakukan migrasi. Hal ini dikarenakan tidak adanya kegiatan di bidang pertanian yang dapat dilakukan jika tidak mempunyai lahan, sehingga masyarakat cenderung mencari pekerjaan lain. Hal ini sesuai pendapat
20 100

Wafirotin, (2016) memiliki lahan pertanian yang sempit mendorong masyarakat untuk melakukan migrasi. Masyarakat yang tidak memiliki lahan di wilayahnya akan terdorong untuk melakukan migrasi dengan harapan akan mendapatkan kehidupan yang lebih baik di daerah tujuannya.

Kemudian faktor individu juga mempunyai hubungan dengan migrasi penduduk di Kecamatan Padang Tiji Kabupaten Pidie yaitu pada variabel tingkat pendidikan yaitu sebesar $3 \%$ dan status pernikahan sebesar $10 \%$. Sedangkan variabel umur dan jenis kelamin tidak mempunyai hubungan dengan migrasi penduduk secara nonpermanen di Kecamatan Padang Tiji Kabupaten Pidie.

$\mathrm{Hal}$ ini sesuai dengan beberapa penelitian diantaranya adalah penelitian yang dilakukan oleh Maulida, (2013) yaitu keputusan masyarakat untuk melakukan migrasi lebih tergantung pada perbedaan upah riil antara pedesaan dan perkotaan. Dimana perbedaan upah antara desa dengan kota terjadi dan memungkinkan adanya pekerjaan yang lebih baik di daerah perkotaan. Adapun faktor lainnya yaitu status pernikahan dan adanya fasilitas pendidikan yang lebih baik di daerah tujuan baik untuk dirinya maupun keluarganya. Data lengkap faktorfaktor yang berhubungan dengan migrasi nonpermanen dapat dilihat pada Tabel 3.

Tabel 3. Faktor-Faktor yang Berhubungan dengan Migrasi Nopermanen

\begin{tabular}{ccccc}
\hline No & Faktor & Variabel & Frekuensi $(\mathrm{n})$ & Presentase $(\%)$ \\
\hline \multirow{2}{*}{1} & \multirow{2}{*}{ Faktor Pendorong } & Pekerjaan didaerah asal & 3 & 10 \\
& & Pendapatan didaerah asal & 2 & 7 \\
\hline
\end{tabular}




\begin{tabular}{|c|c|c|c|c|}
\hline & & $\begin{array}{l}\text { Kepemilikan Lahan } \\
\text { Bencana alam }\end{array}$ & $\begin{array}{l}1 \\
0\end{array}$ & $\begin{array}{l}3 \\
0\end{array}$ \\
\hline \multirow{4}{*}{2} & \multirow{4}{*}{ Faktor Penarik } & Pekerjaan didaerah tujuan & 5 & 17 \\
\hline & & Pendapatan didaerah tujuan & 8 & 27 \\
\hline & & Fasilitas pendidikan & 6 & 20 \\
\hline & & Fasilitas kota & 1 & 3 \\
\hline \multirow{5}{*}{3} & \multirow{4}{*}{ Faktor Individu } & Umur & 0 & 0 \\
\hline & & Tingkat pendidikan & 1 & 3 \\
\hline & & Status pernikahan & 3 & 10 \\
\hline & & Jenis kelamin & 0 & 0 \\
\hline & & & 30 & 100 \\
\hline
\end{tabular}

\section{Pola Migrasi}

Pola migrasi merupakan bentuk dari perpindahan masyarakat dari suatu daerah ke daerah lain. Migrasi dapat dikelompokkan menjadi 2 yaitu migrasi permanen dan nonpermanen. Adapun pola migrasi yang dilakukan oleh penduduk di Kecamatan Padang Tiji Kabupaten Pidie seperti terlihat pada Tabel 4.

Tabel 4. Pola Migrasi Penduduk di Kecamatan Padang Tiji Kabupaten Pidie

\begin{tabular}{llcc}
\hline No & Pola Migrasi & Frekuensi $(\mathrm{n})$ & Presentase $(\%)$ \\
\hline 1 & Permanen & 20 & 40 \\
2 & Nonpermanen & 30 & 60 \\
\hline Total & & 50 & 100 \\
\hline
\end{tabular}

Berdasarkan Tabel 4, dapat dilihat bahwa jumlah penduduk yang migrasi secara non permanen lebih banyak dibandingkan dengan migrasi permanen yaitu sebanyak 30 orang atau $60 \%$ dan migrasi permanen sebanyak 20 orang atau $40 \%$ dari 50 responden. Adapun faktor-faktor yang mempengaruhi terjadinya migrasi non permanen ialah salah satunya pada faktor usia. Penduduk pada saat umurnya tua akan kembali ketempat asalnya karena lebih nyaman berada di daerah asal. Penduduk yang melakukan migrasi pergi hanya untuk mencari pekerjaan dan penghidupan yang lebih layak. Setelah terpenuhi harapannya maka orang tersebut kebanyakan akan lebih memilih kembali ke tempat asalnya.
Menurut hasil penelitian Febriadi et al., (2019) produktivitas kerja akan mengalami penurunan disebabkan bertambahnya umur. Bertambahnya umur migran akan berdampak terhadap menurunnya produktivitas kerja, sehingga harapan para migran untuk mendapatkan sesuatu yang di inginkan di wilayah tujuan akan sulit didapatkan. Selain itu, masyarakat yang berumur lebih tua memiliki minat migrasi yang semakin menurun sehingga akan kembali ke daerah asalnya. Serupa dengan pendapat Sundari et al., (2020) bahwa masyarakat yang usianya lebih tua biasanya lebih nyaman di daerah asal dan menolak untuk pindah. Faktor lainnya yang mempengaruhi migrasi nonpermanen ialah kepemilikan lahan. 
Menurut penelitian $\mathrm{Hu}$ et al., (2011) masyarakat yang memiliki lahan pertanian dan lahan rumah di wilayah asal cenderung tidak memilih migrasi secara permanen. Mereka lebih memilih melakukan migrasi sirkuler, dengan tetap tinggal di daerah asal. Adapun faktor-faktor yang mempengaruhi terjadinya migrasi permanen ialah didominasi oleh status penikahan. Menurut Syairozi \& Wijaya, (2020) orang yang memiliki status menikah lebih banyak melakukan migrasi secara permanen dikarenakan orang yang sudah menikah akan mengikuti suami ataupun sebaliknya. Adapun faktor lainnya ialah faktor pekerjaan di daerah tujuan, adanya fasilitas pendidikan yang lebih baik dan juga tersedianya fasilitas kota sehingga penduduk tersebut memutuskan untuk menetap didaerah tersebut.

Pemilihan lokasi migrasi berdasarkan pada kriteria individu tersebut. Kota Banda Aceh merupakan salah satu kota yang menjadi tujuan migrasi tertinggi yaitu sebanyak 17 orang atau $34 \%$. Kemudian daerah tujuan migrasi tertinggi kedua ialah kota medan yaitu sebanyak 12 orang atau 24 $\%$. Setelah itu, Negara Malaysia juga menjadi salah satu tujuan migrasi sebanyak 5 orang atau $10 \%$. Kemudian sisanya yaitu tersebar ke berbagai kabupaten di Provinsi Aceh, dan terdapat juga di Jakarta, Jawa, dan Lampung. Untuk lebih jelasnya dapat dilihat pada Tabel 5.

Tabel 5. Lokasi Tujuan Para Migran di Kecamatan Padang Tiji Kabupaten Pidie

\begin{tabular}{llcc}
\hline No & Lokasi Migrasi & Jumlah (orang) & Presentase $(\%)$ \\
\hline 1 & Banda Aceh & 17 & 34 \\
2 & Aceh Besar & 2 & 4 \\
3 & Lhokseumawe & 2 & 4 \\
4 & Meulaboh & 2 & 4 \\
5 & Sabang & 2 & 4 \\
6 & Langsa & 1 & 2 \\
7 & Takengon & 1 & 2 \\
8 & Aceh Tamiang & 1 & 2 \\
9 & Pidie Jaya & 1 & 2 \\
10 & Medan & 12 & 24 \\
11 & Jawa & 1 & 2 \\
12 & Jakarta & 1 & 2 \\
13 & Lampung & 2 & 4 \\
14 & Malaysia & 5 & 10 \\
\hline & Total & 50 & 100 \\
\hline
\end{tabular}

Berdasarkan Tabel 5, dapat diketahui bahwa daerah tujuan migrasi bukan hanya di Kabupaten-Kabupaten di Provinsi Aceh saja. Akan tetapi juga tersebar ke luar kota (Medan, Jakarta, Jawa, dan Lampung) dan juga keluar negeri seperti Negara Malaysia. Adapun alasan responden memilih migrasi ke luar kota ialah pekerjaan lebih mudah didapat, adanya kerabat didaerah tujuan, dan pendapatan yang diperoleh lebih tinggi. Keputusan migran ke negara Malaysia dalam mencari pekerjaan baru yang dirasa lebih menjanjikan dari daerah asalnya. Alasan lainnya adalah Malaysia

Jurnal IImu Sosial dan Humaniora | 427 
dianggap dekat dengan Indonesia memudahkan dalam migrasi. Alasan yang menarik minat migran dalam melakukan migrasi ke Negara Malaysia yaitu karena gaji yang ditawarkan disana lebih tinggi dalam bentuk mata uang asing. Nilai tukar rupiah dengan mata uang asing sangatlah rendah, hal ini menyebabkan gaji/upah yang diberikan dalam mata uang asing sangat menggiurkan.

\section{SIMPULAN DAN SARAN}

Hasil penelitian menunjukkan
bahwa faktor-faktor yang
berhubungan dengan migrasi permanen dan nonpermanen yang paling banyak pada responden yaitu faktor penarik, faktor individu dan faktor pendorong. Kemudian Pola migrasi para migran di Kecamatan Padang Tiji Kabupaten Pidie yang paling banyak adalah migrasi secara non permanen sebanyak $60 \%$ dari 50 jumlah responden. Sedangkan migrasi permanen sebanyak $40 \%$ dari 50 jumlah responden.

Peneliti memberikan saran berdasarkan hasil penelitian dan pembahasan yaitu untuk pamangku kepentingan atau pemerintah perlu membangkitkan dan menumbuhkan usaha-usaha milik masyarakat yang ada di desa, serta memberikan motivasi dan fasilitas untuk masyarakat yang berpendidikan tinggi untuk dapat berwirausaha agar terserapnya tenaga kerja dan dapat mengurangi angka pengangguran di desa sehingga akan mengurangi migrasi dari desa ke kota.

Sedangkan saran untuk peneliti selanjutnya agar melakukan penelitian lanjutan dengan melihat variabel yang lain untuk mengetahui faktor-faktor yang berhubungan dengan migrasi dan pola migrasi dan lainnya.

\section{DAFTAR PUSTAKA}

Badan Pusat Statistik. (2019). Kabupaten Pidie Dalam Angka.

Febriadi, Y., Michael, M., \& Amalia, S. (2019). Hubungan antara faktor sosial ekonomi dengan migrasi permanen di kecamatan samarinda ulu kota samarinda. Jurnal IImu Ekonomi Mulawarman (JIEM), 3(4). Gunawan, E. (2016). Fenomena Migrasi Tenaga Kerja Pertanian Dandampaknya terhadap Pemberdayaan Petani di Propinsi Jawa Tengah. Jurnal Ekonomi Dan Pembangunan, 24(2), 97-105.

Hu, F., Xu, Z., \& Chen, Y. (2011). Circular migration, or permanent stay? Evidence from China's ruralurban migration. China Economic Review, 22(1), 64-74. https://doi.org/10.1016/j.chieco.20 10.09 .007

Mantra, I. B. (2015). Demografi Umum. Pustaka Pelajar.

Maulida, Y. (2013). Pengaruh Tingkat Upah terhadap Migrasi Masuk di Kota Pekanbaru. Jurnal Ekonomi, 21(02).

Pratama, A. M. (2012). Analisis FaktorFaktor Yang Mendorong Seseorang Untuk Melakukan Migrasi Ulang-Alik (Studi Kasus Pada Migran Kota Malang Yang Melakukan Migrasi Ulang-Alik Ke Surabaya Dengan Menggunakan Transportasi Bus). Jurnal IImiah Mahasiswa FEB, 1(2).

Jurnal IImu Sosial dan Humaniora | 428 
Puspitasari, A. W., \& Mudakir, B. (2010). Analisis faktor-faktor yang mempengaruhi minat Migrasi sirkuler ke Kabupaten Semarang.

Rahmi, A., \& Rudiarto, I. (2013). Karakteristik migrasi dan dampaknya terhadap pengembangan pedesaan kecamatan kedungjati, kabupaten grobogan. Jurnal Pembangunan Wilayah Dan Kota, 9(4), 331-342.

Sudibia, I. K., Dayuh Rimbawan, I. N., \& Adnyana, I. B. (2012). Pola migrasi dan karakteristik migran berdasarkan hasil sensus penduduk 2010 di Provinsi Bali. Piramida, 8(2), 59-75.

Sukamdi, Mujahid, \& Ghazy. (2015). Internal Migrations in Indonesia. In UNFPA Indonesia: Vol. Monografi Series 3. UNFPA Indonesia.

Sundari, N. I. P. F., Karismawan, P., \& Salmah, E. M. Y. (2020). Fenomena Migrasi Sirkuler Di Kota Mataram. Ganec Swara, 14(1), 557-565.

Susilowati, S. H. (2005). Dampak Mobilitas Tenaga Kerja Terhadap Pendapatan Rumah Tangga Pedesaan. SOCA: Jurnal Sosial Ekonomi Pertanian, 5(1), 43914.

Syairozi, M. I., \& Wijaya, K. (2020). Migrasi Tenaga Kerja Informal: Studi Pada Kecamatan Sukorejo Kabupaten Pasuruan. Seminar Nasional Sistem Informasi (SENASIF), 4(1), 2383-2394.

Syamsuddin, S. (2020). Analisis Determinasi Migrasi Tidak Permanen Antar Daerah Di Provinsi Sumatera Barat. E-Jurnal Ekonomi Dan Bisnis Universitas Udayana, 9, 99-128.
Tajuddin, L., Rijanta, R., Yunus, H. S., \& Giyarsih, S. R. (2015). Migrasi Internasional Perilaku Pekerja Migran di Malaysia dan Perempuan Ditinggal Migrasi di Lombok Timur. Jurnal Kawistara, 5(3).

Todaro, M. P. (1993). Kajian Ekonomi Migrasi Internal di Negara Berkembang. Pusat Penelitian Kependudukan UGM.

Todaro, M. P., \& Smith, S. C. (2003). Pembangunan Ekonomi: Di Dunia Ketiga, Jilid 1.

Trendyari, A. A. T., \& Yasa, I. N. M. (2014). Analisis faktor-faktor yang mempengaruhi migrasi masuk ke kota Denpasar. E-Jurnal Ekonomi Pembangunan Udayana, 3(10), 476-484.

Wafirotin, K. Z. (2016). Dampak Migrasi Terhadap Kondisi Sosial Ekonomi Keluarga TKI di Kecamatan Babadan Kabupaten Ponorogo. Ekuilibrium: Jurnal IImiah Bidang Ilmu Ekonomi, 8(1), 15-33. 